\title{
Efektivitas Ekstrak Daun Kersen untuk Pengobatan Benih Ikan Nila yang Terinfeksi Bakteri Aeromonas hydrophila
}

The Efectivity of Jamaican Cherry Leaves Extract for Treating Infected Tilapia Juvenile by Aeromonas hydrophila

\author{
Rosidah* Walim Lili*, Iskandar* Muhammad Rionaldhie Afpriliansyah** \\ *) Dosen Fakultas Perikanan dan Ilmu Kelautan Universitas Padjadjaran \\ **) Alumni Fakultas Perikanan dan Ilmu Kelautan Universitas Padjadjaran \\ Program Studi Perikanan, Fakultas Perikanan Dan Ilmu Kelautan Universitas adjadjaran \\ Jalan Raya Bandung - Sumedang Km 21 Jatinangor 40600 Sumedang Jawa Barat \\ E-mail : rosahdi@yahoo.com
}

\begin{abstract}
Abstrak
Penelitian ini bertujuan untuk menentukan konsentrasi ekstrak daun kersen (Muntingia calabura) yang efektif untuk pengobatan benih ikan nila (Oreochromis niloticus) yang diinfeksi bakteri Aeromonas hydrophila sehingga menghasilkan sintasan benih ikan nila yang tertinggi. Rancangan percobaan yang digunakan adalah rancangan acak lengkap (RAL) dengan lima perlakuan dan tiga ulangan. Perlakuan yang digunakan adalah perendaman ikan nila yang terinfeksi Aeromonas hydrophila dalam ekstrak daun kersen dengan konsentrasi 0, 40, 60, 80, dan 100 ppm. Parameter yang diamati adalah gejala klinis, respon ikan terhadap pakan, respon ikan terhadap kejutan dan kelangsungan hidup pada masing-masing perlakuan. Hasil penelitian memperlihatkan penggunaan ekstak daun kersen dengan konsentrasi 60 ppm efektif untuk mengobati benih ikan nila yang terinfeksi bakteri Aeromonas hydrophila, menghasilkan pemulihan tercepat yaitu hari keempat dan tingkat kelangsungan hidup tertinggi sebesar $81,67 \%$.
\end{abstract}

Kata kunci: Aeromonas hydrophila, Benih ikan nila, Ekstrak daun kersen

\begin{abstract}
This research aims to find out the concentration of Jamaican cherry leaf extract (Muntingia calabura) effective for the treatment of tilapia juvenile (Oreochromis niloticus) infected by Aeromonas hydrophila bacteria to produce the highest survival of tilapia juvenile. The experimental design used a complete randomized design (CRD) with five treatments and three replications. The concentration of Jamaican cherry leaf extract is $0,40,60,80$, and $100 \mathrm{ppm}$. The parameters observed were clinical symptoms, fish response to feed, fish response to shock and survival in each treatment.The results showed the use of kersen leaf extract with $60 \mathrm{ppm}$ concentration effective to treat the seeds of tilapia infected with Aeromonas hydrophila bacteria, resulting in the fastest recovery of the fourth day and the highest survival rate of $81.67 \%$.
\end{abstract}

Keyword : Aeromonas hydrophila, Nile tilapia juvenile, Jamaican cherry leaves extract 


\section{Pendahuluan}

Ikan nila (Oreochromis niloticus) merupakan salah satu komoditas unggulan air tawar yang memiliki nilai ekonomi cukup tinggi. Walaupun ikan nila dikenal sebagai ikan yang kuat terhadap kualitas air yang rendah, namun beberapa jenis penyakit dapat menyerang ikan nila yang dibudidayakan.

Salah satu penyakit yang menyerang ikan nila dari golongan bakteri adalah bakteri Aeromonas hydrophila. Bakteri $A$. hydrophila menyerang ikan nila pada berbagai ukuran dari ukuran benih sampai ukuran konsumsi, namun nila pada ukuran benih lebih rentan terhadap serangan bakteri ini, dapat menyebabkan kematian hingga mencapai $80 \%$, sehingga mengakibatkan kerugian yang sangat besar dalam kegiatan usaha budidaya (Sanoesi, 2008).

Salah satu cara yang relatif aman baik bagi ikan maupun lingkungan untuk mengobati infeksi $A$. hydrophila adalah dengan menggunakan tanaman sebagai obat herbal. Selain aman obat herbal cukup murah dan mudah untuk ditemukan. Tanaman yang dapat digunakan sebagai obat herbal salah satunya adalah tanaman kersen. Ekstrak dari daun kersen dengan pelarut etanol 96\% mengandung kelompok senyawa alkaloid, flavonoida, kuinon, triterpen, dan saponin yang berperan sebagai anti-bakteri alami (Amiruddin, 2007).

Menurut Noorhamdani dkk (2010) kemampuan yang dimiliki flavonoid pada daun kersen dalam memberikan efek antibakteri antara lain dengan menghambat fungsi membran sitoplasma, menghambat sintesis asam nukleat, menghambat aktivitas bakteri dengan jalan menghambat metabolisme energi dan flavonoid dapat menghambat konsumsi oksigen dengan jalan mengganggu rantai transport elektron respirasi.

Saponin memiliki molekul yang dapat menarik air atau hidrofilik dan molekul yang dapat melarutkan lemak atau lipofilik (Dwijoseputro, 1994). Mekanisme kerja saponin sebagai antibakteri adalah menurunkantegangan permukaan sehingga mengakibatkan naiknya permeabilitas ataukebocoran sel dan mengakibatkan senyawa intraseluler akan keluar (Robinson, 1995).

Tujuan dari penelitian ini adalah untuk menentukan konsentrasi ekstrak daun kersen (Muntingia calabura) yang efektif untuk pengobatan benih ikan nila (Oreochromis niloticus) yang diinfeksi bakteri A. hydrophila.

\section{Bahan dan metode}

Bahan yang digunakan dalam penelitian ini antara lain, benih ikan nila hitam (Oreochromis niloticus) yang berasal dari BBI Cibiru sebanyak 600 ekor dengan ukuran 7-9 cm, daun kersen sebagai bahan herbal untuk pengobatan benih ikan yang terinfeksi bakteri Aeromonas hydrophila, isolat bakteri Aeromonas hydrophila diperoleh dari BBPBAT Sukabumi, pakan ikan komersil, Etanol 96\% sebagai pelarut dalam pembuatan ekstrak, $\mathrm{NaCl}$ fisiologis $0,9 \%$ sebagai pelarut dalam pembuatan larutan suspensi bakteri, alkohol $70 \%$ dan akuades steril untuk sterilisasi alat dan pengenceran, Nutrient agar sebagai media kultur bakteri $A$. hydrophila.

Penelitian pendahuluan dilaksanakan pada tanggal 6-21 Februari 2017, meliputi uji $\mathrm{LC}_{50}$ yang dilakukan di Laboratorium Fisiologi Hewan Air Gedung 2, pembuatan ekstrak daun kersen dilakukan di Laboratorium Farmakognosi dan Bahan Alam, Fakultas Farmasi Universitas Padjadjaran, skrining fitokimia dilakukan di Laboratorium Sentral Universitas Padjadjaran, uji daya hambat dilakukan di Laboratorium Bioteknologi Universitas Padjadjaran. Penelitian utama dilaksanakan pada bulan Juni sampai dengan Juli 2017 di Laboratorium Akuakultur Fakultas Perikanan dan Ilmu Kelautan Universitas Padjadjaran.

Penelitian ini menggunakan metode eksperimental dengan Rancangan Acak Lengkap (RAL) yang terdiri dari 5 (lima) perlakuan dan 3 (tiga) kali pengulangan. Setiap perlakuan menggunakan 20 ekor benih ikan nila. Perlakuan yang diberikan yaitu perendaman benih ikan nila yang 
diinfeksi bakteri Aeromonas hydrophila dalam ekstrak daun kersen selama 24 jam dengan konsentrasi $0 \mathrm{ppm}, 40 \mathrm{ppm}, 60$ ppm, $80 \mathrm{ppm}$, dan $100 \mathrm{ppm}$. Konsentrasi yang digunakan berdasarkan hasil penelitian pendahuluan yang telah dilakukan. Uji $\mathrm{LC}_{50} 24$ jam dianalisis dengan menggunakan software EPA Probhit Analisys memperlihatkan nilai $\mathrm{LC}_{50}$ 24 jam sebesar 160 ppm, Nilai LC $_{50} 24$ jam menunjukkan bahwa pada konsentrasi 160 ppm ekstrak daun kersen dapat mengakibatkan mortalitas benih ikan nila sebesar 50\% dalam waktu 24 jam. Dari uji in vitro diketahui konsentrasi $125 \mathrm{ppm}$ memiliki rata-rata zona daya hambat terbesar, akan tetapi konsentrasi yang tinggi akan berdampak pada kelangsungan hidup ikan, oleh karena itu penggunaan konsentrasi $60 \mathrm{ppm}$ diduga efektif karena mendekati konsentrasi 75 ppm dengan ratarata zona daya hambat hampir sama dengan 125 ppm, dengan konsentrasi 60 ppm yang menjauhi nilai $\mathrm{LC}_{50}$ diharapkan dapat mengurangi mortalitas ikan yang diuji.

\section{Hasil dan pembahasan}

Benih ikan nila yang telah terinfeksi bakteri Aeromonas hydrophila ditandai dengan munculnya gejala klinis berupa kerusakan di permukaan tubuh ikan, respon terhadap pakan dan respon terhadap kejutan. Setelah 24 jam penginfeksian dengan bakteri Aeromonas hydrophyla kurang dari 50\% benih ikan nila mulai nampak gejala klinis terserang bakteri tersebut. Gejala klinis yang terlihat adalah adanya kerusakan di permukaan tubuh ikan berupa bercak merah (haemoraghic) (Gambar 1a), warna tubuh ikan menjadi gelap, perut membuncit (dropsy) (Gambar 1b), dan mata menonjol (exopthalmia) (Gambar 1c). Sebagaimana pendapat Lubis et al. (2014), sampel ikan yang terserang bakteri A.hydrophila memiliki gejala klinis warna tubuh gelap, timbul pendarahan pada kulit sampai luka-luka dan borok, perut kembung (dropsy), mata rusak atau menonjol, sirip geripis dan bergerak lambat. Gejala klinis lain terjadi pendarahan pada hati, ginjal dan limfa saat dilakukan pembedahan. Menurut Austin dan Austin (1999), ikan yang mengalami dropsy diakibatkan oleh adanya pelepasan Aerolysin Cytotoxic Enterotoxyn dari bakteri $A$. hydrophila yang menyebabkan kerusakan jaringan ikan.

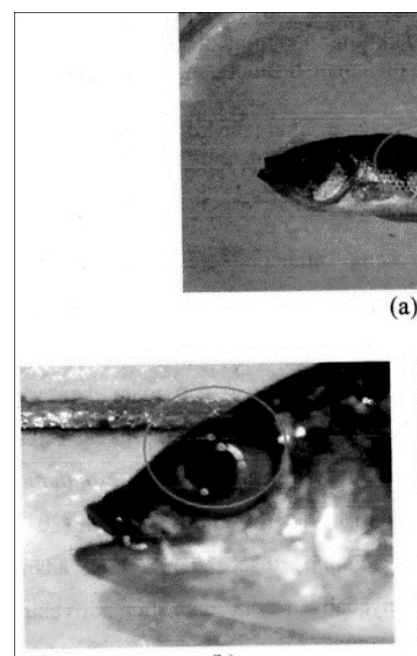

(b)

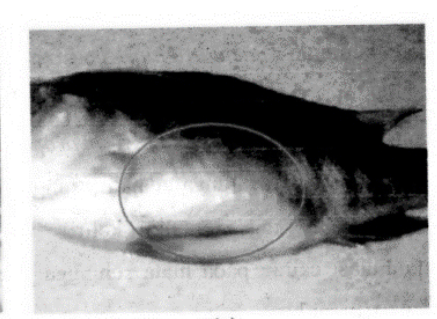

(c)

Gambar 1. Gejala klinis Benih Ikan Nila yang Terinfeksi Aeromonas hydrophila (a) bercak merah (b) mata menonjol (exopthalmia) (c) Perut membuncit (dropsy)

Figure 1. Clinical Symptoms of Infected Nile tilapia juvenile of Aeromonas hydrophila (a) Haemoraghe (b) exopthalmia (c) dropsy 
Rosidah : Efektivitas Ekstrak Daun Kersen untuk Pengobatan Benih Ikan Nila yang Terinfeksi Bakteri Aeromonas hydrophila

Dalam waktu 72 jam pasca penginfeksian dengan bakteri A. hydrophila lebih dari $50 \%$ ikan uji telah menunjukkan gejala klinis terinfeksi bakteri tersebut. Kemudian ikan uji segera dilakukan pengobatan dengan ekstrak daun kersen melalui perendaman selama 24 jam dengan konsentrasi ekstrak sesuai perlakuan, yaitu A (0 ppm/kontrol), B (40 ppm), C (60 ppm), D (80 ppm), dan E (100 ppm). Gejala klinis yang diamati pasca perendaman ikan dalam ekstrak daun kersen meliputi kerusakan di permukaan tubuh, respon ikan terhadap pakan, respon ikan terhadap kejutan, dan kualitas air akuarium pada setiap perlakuan.

\section{Pemulihan Kerusakan Permukaan Tubuh}

Setelah ikan uji yang terinfeksi $A$. hydrophila dan menunjukkan gejala klinis dilakukan pengobatan dengan ekstrak daun kersen selama 24 jam, kemudian dilakukan pemeliharaan dan pengamatan selama 14 hari untuk melihat ada tidaknya pemulihan yang terjadi dari gejala klinis yang muncul setelah dilakukan pengobatan. Pengamatan yang diamati berupa dropsy (D), exopthalmia (E), sirip geripis $(\mathrm{G})$, haemoraghic $(\mathrm{H})$ diskolorisasi/Perubahan warna (W) (Tabel 1).

Tabel 1. Pemulihan Kerusakan Tubuh Ikan Uji Setelah Direndam Ekstrak Daun Kersen

Table 1. Recovery of Body Fish Damage After Treatment with Jamaican cherry leaves extract

\begin{tabular}{|c|c|c|c|c|c|}
\hline \multirow[b]{2}{*}{ Hari ke- } & \multicolumn{5}{|c|}{ Konsentrasi Ekstrak Daun Kersen (ppm) } \\
\hline & $\begin{array}{c}\mathrm{A} \\
(0 \mathrm{ppm})\end{array}$ & $\begin{array}{c}\text { B } \\
(40 \mathrm{ppm})\end{array}$ & $\begin{array}{c}\mathrm{C} \\
(60 \mathrm{ppm})\end{array}$ & $\begin{array}{c}\mathrm{D} \\
(80 \mathrm{ppm})\end{array}$ & $\begin{array}{c}E \\
(100 \mathrm{ppm})\end{array}$ \\
\hline 1 & EDWGH & EDWGH & EDWGH & EDWGH & EDWGH \\
\hline 2 & EDWGH & EDWGH & EDWGH & EDWGH & EDWGH \\
\hline 3 & EDWGH & EDWGH & EDWGH & EDWGH & EDWGH \\
\hline 4 & EDWGH & EDWG & DWG & DWG & DWG \\
\hline 5 & EDWGH & DWG & DWG & DWG & DWG \\
\hline 6 & EDWGH & DWG & DW & DW & DW \\
\hline 7 & EDWGH & WG & $\mathrm{W}$ & W & $\mathrm{W}$ \\
\hline 8 & EDWGH & $\mathrm{W}$ & W & $\mathrm{W}$ & $\mathrm{W}$ \\
\hline $9-14$ & EDWGH & S & S & S & S \\
\hline $\begin{aligned} \text { ngan : } & \text { (E) } \\
& \text { (D) } \\
& \text { (W) }\end{aligned}$ & $\begin{array}{l}\text { : Exopth } \\
\text { : Dropsy } \\
\text { : Diskolc }\end{array}$ & asi /Perul & han warna & $\begin{array}{ll}\text { (G) }: \mathrm{S} \\
(\mathrm{H}): H \\
(\mathrm{~S}): \mathrm{S}\end{array}$ & $\begin{array}{l}\text { Geripis } \\
\text { moraghic } \\
\text { buh }\end{array}$ \\
\hline
\end{tabular}

Tabel 1 memperlihatkan pada hari ke-1 hingga hari ke -3 setelah pengobatan dengan ekstrak daun kersen, gejala klinis berupa exopthalmia, dropsy, diskolorisasi, sirip geripis dan haemoraghic masih nampak pada ikan uji di setiap perlakuan, ikan terlihat seperti kekurangan oksigen, pergerakan sangat lambat dan selalu berkumpul disekitar batu aerasi.

Pada hari ke-4 dan ke-5 masa pemeliharaan gejala klinis berupa haemoraghic nampak adanya pemulihan pada semua perlakuan. Perlakuan C (60 ppm), D (80 ppm), dan E (100 ppm) gejala klinis berupa exopthalmia terjadi pemulihan pada hari ke-4. Namun ikan uji pada perlakuan A (kontrol) mengalami kondisi gejala klinis yang semakin buruk, hal ini disebabkan karena perlakuan A (kontrol) tidak diberi ekstrak daun kersen.

Pada hari ke-6 hingga ke-8 masa pemeliharaan rata-rata ikan pada setiap perlakuan sudah terlihat tanda-tanda pulih dari gejala klinis, bercak di tubuh ikan sudah menghilang mengindikasikan ikan sudah mengalami proses pemulihan. Bagian perut yang membuncit (dropsy) terlihat berangsur-angsur menghilang dari tubuh ikan uji. 
Pada hari ke-9 hingga hari ke-14 kerusakan pada permukaan tubuh ikan sudah menghilang, kulit dan sisik ikan nampak hampir normal kembali. Pada perlakuan A (kontrol), kondisi ikan tidak terlihat adanya penyembuhan dari gejala yang ditimbulkan oleh $A$. hydrophila, exopthalmia (Gambar 2a), dropsy (Gambar 2b), dan sirip geripis (Gambar 2c) semakin parah.

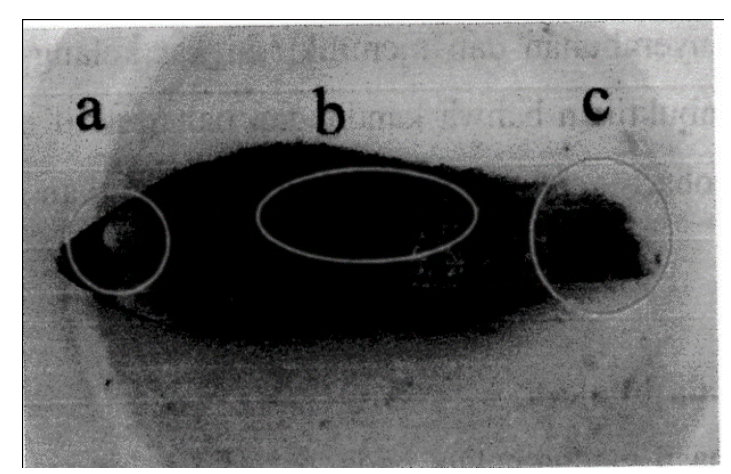

Gambar 2. Kondisi Ikan Uji perlakuan A (kontrol)

(a) Mata menonjol (exopthalmia), (b) dropsy (c) sirip geripis

Figure 2. Fish condition After Treatment (control)
(a) exopthalmia
(b) dropsy
(c) flipper fins

\section{Respon Terhadap Pakan}

Pengamatan respon ikan uji terhadap pakan sama dengan pengamatan terhadap pemulihan kerusakan tubuh dilakukan selama 14 hari dari masa pemeliharaan. Berdasarkan hasil pengamatan respon ikan terhadap pakan pasca pengobatan untuk setiap perlakuan berbeda-beda (Tabel 2).

Tabel 2. Respon Benih Ikan Nila Terhadap Pakan

Table 2. Response of Nile Tilapia Juvenil to Feed

\begin{tabular}{|c|c|c|c|c|c|c|c|c|c|c|c|c|c|c|c|}
\hline \multirow{3}{*}{ Hari } & \multicolumn{15}{|c|}{ Perlakuan } \\
\hline & \multicolumn{3}{|l|}{$\mathbf{A}$} & \multicolumn{3}{|l|}{$\mathbf{B}$} & \multicolumn{3}{|l|}{$\mathbf{C}$} & \multicolumn{3}{|l|}{ D } & \multicolumn{3}{|l|}{$\mathbf{E}$} \\
\hline & 1 & 2 & 3 & 1 & 2 & 3 & 1 & 2 & 3 & 1 & 2 & 3 & 1 & 2 & 3 \\
\hline 1 & - & - & - & - & - & - & - & - & - & - & - & - & - & - & - \\
\hline 2 & - & - & - & - & - & - & - & - & - & - & - & - & - & - & - \\
\hline 3 & - & - & - & - & - & - & + & + & + & + & + & + & - & - & - \\
\hline 4 & - & - & - & + & + & + & + & + & + & + & + & + & + & + & + \\
\hline 5 & - & - & - & + & + & + & + & ++ & ++ & + & + & + & + & + & + \\
\hline 6 & - & - & - & ++ & + & ++ & ++ & ++ & ++ & ++ & ++ & ++ & + & + & + \\
\hline 7 & + & + & - & ++ & ++ & ++ & ++ & ++ & ++ & ++ & ++ & ++ & ++ & ++ & ++ \\
\hline $8-11$ & + & + & + & ++ & ++ & ++ & ++ & ++ & ++ & ++ & ++ & ++ & ++ & ++ & ++ \\
\hline $\begin{array}{l}12- \\
14\end{array}$ & + & - & + & ++ & ++ & ++ & ++ & ++ & ++ & ++ & ++ & ++ & ++ & ++ & ++ \\
\hline & $\begin{array}{l}-9 \\
(+) \\
(++)\end{array}$ & $\begin{array}{l}\text { Resp } \\
\text { Resp } \\
\text { Resp }\end{array}$ & & lap & kan & goj & akan & $\mathrm{dak}$ & rsisa) & & & & & & \\
\hline
\end{tabular}


Rosidah : Efektivitas Ekstrak Daun Kersen untuk Pengobatan Benih Ikan Nila yang Terinfeksi Bakteri Aeromonas hydrophila

Tabel 2 memperlihatkan respon ikan terhadap pakan pada perlakuan B (40 ppm), C (60 ppm). D (80 ppm), E (100 ppm) berbeda dengan perlakuan A (kontrol), dimana ikan yang diberi perlakuan (dilakukan pengobatan) dengan ekstrak daun kersen akan mengalami penyembuhan dan diiringi dengan meningkatnya respon terhadap pakan. Respon pakan ikan pada perlakuan B (40 ppm) baru terlihat pada hari ke-4. Pada hari ke-5 sampai akhir masa pemeliharaan ikan memiliki respon pakan yang terus meningkat dari hari ke hari hingga terlihat normal pada akhir pengamatan (hari ke-14). Pada hari ke-3 ikan uji perlakuan $\mathrm{C}(60 \mathrm{ppm})$ respon pakan masih rendah dan mulai terlihat normal pada hari ke-5 hingga akhir pengamatan (hari ke-14).

Ikan uji pada perlakuan D (80 ppm) respon terhadap pakan muncul pada hari ke3 tetapi masih rendah hingga hari ke-5. Pada hari ke-6 hingga akhir masa pemeliharaan respon pakan kembali normal.

Ikan uji pada perlakuan E (100 ppm) tidak ada respon terhadap pakan hingga hari ke-3 masa pemeliharaan, namun pada hari ke-4 sampai hari ke-6 masa pemeliharaan mulai terlihat respon yang rendah terhadap pakan. Pada hari ke-7 hingga akhir masa pemeliharaan respon terhadap pakan kembali normal.

Pada perlakuan D (80 ppm) respon terhadap pakan muncul pada hari ke-3 tetapi rendah hingga hari ke-5, pada hari ke6 hingga akhir masa pemeliharaan respon pakan meningkat kembali normal. Pada perlakuan E (100 ppm) tidak ada respon pakan hingga hari ke-3 masa pemeliharaan, hari ke-4 sampai hari ke-6 masa pemeliharaan baru terlihat respon yang rendah terhadap pakan, hari ke-7 hingga akhir masa pemeliharaan respon terhadap pakan meningkat hingga kembali normal.

\section{Respon Terhadap Kejutan}

Pengamatan respon ikan uji terhadap kejutan sama dengan pengamatan terhadap pemulihan kerusakan tubuh dan respon terhadap pakan dilakukan selama 14 hari dari masa pemeliharaan. Berdasarkan hasil pengamatan respon ikan terhadap kejutan pasca pengobatan untuk setiap perlakuan berbeda-beda (Tabel 3).

Tabel 3. Respon Benih Ikan Nila Terhadap Kejutan

Table 3. Response of Nile tilapia juvenile to Surprises

\begin{tabular}{|c|c|c|c|c|c|c|c|c|c|c|c|c|c|c|c|}
\hline \multirow[t]{3}{*}{ Hari } & \multicolumn{15}{|c|}{ Perlakuan } \\
\hline & \multicolumn{3}{|l|}{$\mathbf{A}$} & \multicolumn{3}{|l|}{ B } & \multicolumn{3}{|l|}{$\mathrm{C}$} & \multicolumn{3}{|l|}{ D } & \multicolumn{3}{|l|}{$\mathbf{E}$} \\
\hline & 1 & 2 & 3 & 1 & 2 & 3 & 1 & 2 & 3 & 1 & 2 & 3 & 1 & 2 & 3 \\
\hline 1 & - & - & - & - & - & - & - & - & - & - & - & - & - & - & - \\
\hline 2 & - & - & - & - & - & - & - & - & - & - & - & - & - & - & - \\
\hline 3 & - & - & - & - & - & - & - & - & - & - & - & - & - & - & - \\
\hline 4 & - & - & - & + & - & + & + & + & + & + & + & + & + & + & + \\
\hline 5 & - & - & - & + & + & + & + & + & + & + & + & + & + & + & + \\
\hline 6 & - & - & - & + & + & + & + & + & + & + & + & + & + & + & + \\
\hline 7 & - & - & - & + & + & + & ++ & ++ & ++ & ++ & ++ & ++ & + & + & + \\
\hline 8 & + & + & + & + & ++ & ++ & ++ & ++ & ++ & ++ & ++ & ++ & ++ & ++ & ++ \\
\hline $9-11$ & + & + & + & ++ & ++ & ++ & ++ & ++ & ++ & ++ & ++ & ++ & ++ & ++ & ++ \\
\hline $\begin{array}{l}12- \\
14\end{array}$ & + & - & + & ++ & ++ & ++ & ++ & ++ & ++ & ++ & ++ & ++ & ++ & ++ & ++ \\
\hline & & & & & & n ting & & & & & & & & & \\
\hline
\end{tabular}

Berdasarkan Tabel 3 terlihat ikan uji yang tidak diberi pengobatan dengan ekstrak daun kersen (perlakuan A/kontrol) memiliki respon yang buruk ketika diuji refleks dengan menepuk dinding akuarium, hal ini menunjukkan ikan dalam kondisi sakit akibat serangan bakteri A.hydrophila. Sedangkan ikan uji yang diberi perlakuan 
perendaman dengan ekstrak daun kersen menunjukan respon yang berbeda terhadap kejutan. Respon terbaik terdapat pada ikan uji perlakuan $\mathrm{C}(60 \mathrm{ppm})$ dan $\mathrm{D}(80 \mathrm{ppm})$ karena pada hari ke-7 pergerakkan ikan sudah kembali normal, jika dibandingkan dengan perlakuan B (40 ppm) dan E (100 ppm).

Kelangsungan Hidup Benih Ikan Nila yang Terinfeksi Aeromonas hydrophila

\section{Setelah Pengobatan dengan Ekstrak Daun Kersen}

Berdasarkan hasil pengamatan, selama 14 hari benih nila hitam yang terinfeksi bakteri A. hydrophila setelah dilakukan pengobatan dengan larutan ekstrak daun kersen melalui metode perendaman selama 24 jam dengan berbagai konsentrasi ekstrak sesuai perlakuan menunjukkan tingkat kelangsungan hidup yang bervariasi pada setiap perlakuan (Gambar 1).

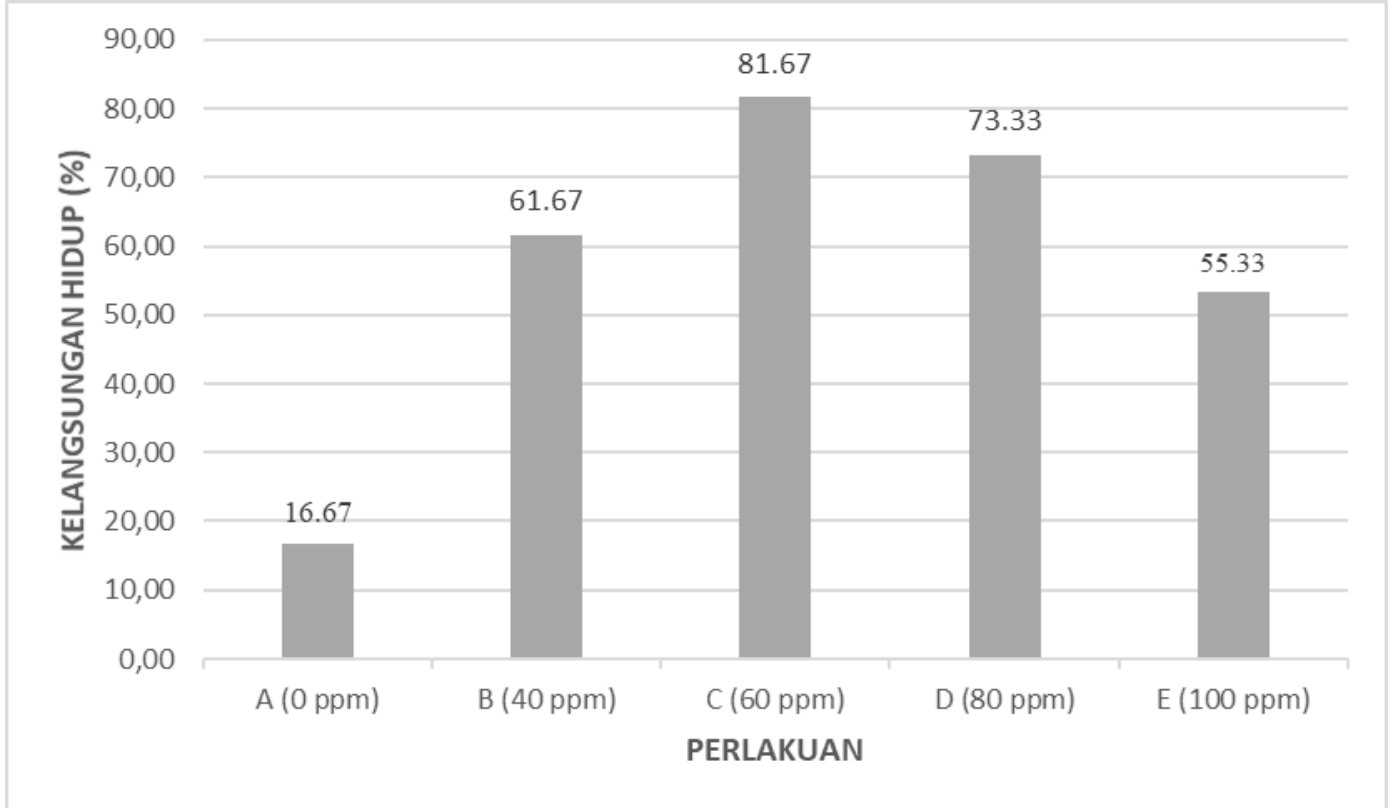

Gambar 1. Grafik Kelangsungan Hidup Benih Ikan Nila

Figure 1: Graph of Survival Rate of Nile tilapia juvenile

Pada Gambar 1 memperlihatkan benih nila hitam yang diobati dengan ekstrak daun kersen memberikan tingkat kelangsungan hidup lebih tinggi $(55,33 \%-81,67 \%)$ dibandingkan dengan perlakuan A (0 ppm) tanpa dilakukan pengobatan. Hal ini menunjukkan bahwa bahan aktif yang terkandung dalam ekstrak daun daun kersen berpotensi untuk menghambat pertumbuhan A. hydrophila yang menginfeksi benih lele sangkuriang. Benih nila hitam pada perlakuan A (kontrol) memiliki tingkat kelangsungan hidup hanya $16,67 \%$, hal ini disebabkan bakteri $A$. hydrophila yang menginfeksi dan masuk ke dalam tubuh benih ikan uji terus berkembang dan merusak organ tubuh benih ikan baik bagian luar maupun dalam, benih ikan uji yang ketahanan tubuhnya rendah akan mengalami kematian. Sebagaimana hasil penelitian yang dilakukan oleh Maulida et.al (2017) dengan menggunakan bahan herbal ekstrak Sambiloto untuk pengobatan benih patin siam yang terinfeksi bakteri $A$. hydrophila memperlihatkan kelangsungan hidup yang lebih tinggi dibandingkan dengan kontrol (tidak dilakukan pengobatan). Kelangsungan hidup benih patin siam yang diobati dengan ekstrak Sambiloto berkisar antara 68,33\% $86,67 \%$, sedangkan yang tidak dilakukan 
pengobatan kelangsungan hidupnya hanya $10 \%$.

Benih ikan uji pada perlakuan B (40 ppm) mengalami peningkatan kelangsungan hidup dibandingkan dengan perlakuan A (kontrol), yaitu sebesar $61,67 \%$. Terjadinya peningkatan kelangsungan hidup pada perlakuan B dipengaruhi oleh aktivitas antibakteri yang terkandung dalam ekstrak daun kersen dapat menghambat pertumbuhan $A$. hydrophila sehingga tingkat infeksi akan menurun dan ikan berangsur pulih, hal ini didukung dengan tingkat pemulihan kerusakan yang lebih cepat dibandingkan dengan perlakuan A (Tabel 1). Sebagaimana menurut Prasetyo dan Sasongko (2014) ekstrak etanol 70\% daun kersen (Muntingia calabura L.) memperlihatkan aktivitas antibakteri terhadap Bacillus subtilis dan Shigella dysenteriae. Kemampuan ekstrak etanol $70 \%$ daun kersen (Muntingia calabura L.) dalam membunuh bakteri karena adanya kandungan senyawa aktif dalam daun kersen, kematian bakteri oleh senyawa antimikroba dapat disebabkan oleh beberapa faktor yaitu mekanisme kerja antibakteri dengan menghambat sintesis dinding sel, menganggu atau merusak dinding sel, dan menghambat sintesis protein.Berdasarkan hasil uji fitokimia yang telah dilakukan senyawa antibakteri yang terkandung dalam ekstrak daun kersen antara lain alkaloid, flavonoid, saponin, dan steroid. Namun bahan antimikroba dalam konsentrasi $40 \mathrm{ppm}$ dirasa kurang cukup untuk mengobati benih ikan nila yang terinfeksi A. hydrophila karena pemulihan gejala klinis pada ikan uji cenderung lebih lama dibandingkan dengan perlakuan $\mathrm{C}$ (60 ppm), D (80 ppm) dan E (100 ppm).

Ikan uji pada perlakuan C (60 ppm) menghasilkan tingkat kelangsungan hidup tertinggi yaitu sebesar $81,67 \%$. Hal ini memperihatkan kandungan bahan antibakterial yang terdapat pada konsentrasi tersebut paling efektif untuk mengobati benih ikan nila yang terinfeksi bakteri A. hydrophila.

Perlakuan D $(80$ ppm $)$ mengalami penurunan tingkat kelangsungan hidup sebesar 73,33\%, hal ini diakibatkan oleh bahan aktif yang terkandung pada ekstrak daun kersen dengan konsentrasi $80 \mathrm{ppm}$ cukup baik untuk mengobati infeksi bakteri A. hydrophila akan tetapi dengan konsentrasi yang lebih tinggi beberapa bahan aktif dapat menjadi racun bagi ikan uji dan dapat mempengaruhi mortalitas pada ikan uji.

Pada perlakuan E (100 ppm) tingkat kelangsungan hidup ikan kembali menurun karena konsentrasi 100 ppm memiliki kandungan bahan antimikroba yang lebih tinggi dan bersifat racun bagi ikan uji, ikan yang dapat bertahan diakibatkan oleh daya tahan tubuh ikan yang berbeda tiap individu.

Flavonoid yang terkandung dalam ekstrak daun kersen bekerja secara aktif sebagai zat antibakteri, mekanisme kerja flavonoid sebagai antibakteri adalah membentuk senyawa kompleks terhadap protein extraseluler yang mengganggu keutuhan membran sel bakteri dengan cara mendenaturasi protein sel bakteri dan merusak membran sel tanpa dapat diperbaiki lagi (Juliantina 2008). Senyawa lain yang berperan aktif dalam pengobatan infeksi adalah senyawa saponin. Menurut Robinson (1995) mekanisme kerja senyawa saponin sebagai yaitu dengan menurunkan tegangan permukaan sehingga mengakibatkan naiknya permeabilitas atau kebocoran sel dan mengakibatkan senyawa intraseluler akan keluar.

Selain flavonoid dan saponin, dalam ekstrak daun kersen terdapat kandungan alkaloid yang berperan sebagai zat antibakteri. Senyawa alkaloid memiliki mekanisme penghambatan dengan cara mengganggu komponen penyusun peptidoglikan pada sel bakteri, sehingga lapisan dinding sel tidak terbentuk secara utuh dan menyebabkan kematian sel tersebut (Juliantina, 2008). Selain itu, menurut Gunawan (2009), di dalam senyawa alkaloid terdapat gugus basa yang mengandung nitrogen akan bereaksi dengan senyawa asam amino yang menyusun dinding sel bakteri dan DNA bakteri. Reaksi ini mengakibatkan terjadinya perubahan struktur dan susunan asam amino, sehingga akan menimbulkan perubahan keseimbangan genetik pada rantai DNA dan terjadinya kerusakan serta 
lisis pada sel bakteri, hal ini mengakibatkan kematian sel bakteri. Menurut Putra (2007), mekanisme kerja steroid dalam menghambat mikroba, adalah dengan merusak membran plasma sel mikroba, sehingga menyebabkan bocor dan sitoplasma keluar sel, akibatnya sel bakteri mengalami kematian.

\section{Kesimpulan}

Berdasarkan hasil penelitian yang telah dilakukan, dapat disimpulkan bahwa ekstrak daun kersen efektif untuk pengobatan benih ikan nila yang terinfeksi Aeromonas hydrophila. Konsentrasi 60 ppm menghasilkan pemulihan tercepat yaitu hari keempat dan tingkat kelangsungan hidup tertinggi yaitu sebesar $81,67 \%$.

\section{Saran}

Disarankan penelitian lanjutan mengenai pengobatan benih ikan nila yang terinfeksi Aeromonas hydrophila dengan menggunakan daun kersen dari bahan segar (simplisia).

\section{Daftar Pustaka}

Amiruddin. 2007. Free radical scavenging activity of some plant available in Malaysia. Iran J Pharm Therap. 6: 87-91.

Dwidjoseputro. 1994. Pengantar Fisiologi Tumbuhan. Jakarta: Penerbit Gramedia Pustaka Utama.

Gunawan, G.S. 2009. Farmakologi dan Terapi edisi 5. Jakarta: Departemen Farmakologi dan Terapeutik Fakultas Kedokteran Universitas Indonesia.

Juliantina., Farida R. Manfaat sirih (Piper crocatum) sebagai agen anti bakterial terhadap gram positif dan gram negatif. JKKI - Jurnal Kedokteran dan KesehatanIndonesia; 2009 No 1 (I).h.5.
Lubis, Y. P. P.; Yunasfi dan R. Leidonald. 2014. Jenis-jenis bakteri padaluka ikan patin. Jurnal Aquacostamarine. 2(1): $\quad$ 6677.

Maulidya, B., Rosidah, Junianto and W. Lili. 2017. Effectivity of Sambiloto Extract as Medicine for Catfish (Pangasius hypophthalmus) Juvenils Infected by Aeromonas hydrophila. International Journal of Fisheries and Aquatic Studies. Vol. 5. Issue 6. Part D : 236-241.

Noorhamdani, Herman dan D. Rosalia. 2010. Uji Ekstrak Daun Kersen (Muntingia calabura) sebagai Antibakteri Terhadap Methicillin Resistant (Staphylococcus aureus MRSA) Secara In Vitro. Laboratorium Mikrobiologi FKUB.

Prasetyo, AD. H. Kasongko. 2014. Aktivitas Antibakteri Ekstrak Etanol 70\% Daun Kersen (Muntianga calabura L.) Terhadap Bakteri Bacillus subtilis dan Shigella dysentriae Sebagai materi pembelajaran Biologi SMA Kelas X untuk Mencapai Kd 3.4 pada Kurikulum 2013. Jupemasi-Pbio. Vol. 1. No. 1. 98-102.

Putra, I.N. K. 2007. Study Daya Antimikroba Ekstrak Beberapa Bahan Tumbuhan Pengawet Nira Terhadap Mikroba Perusak Nira Serta Kandungan Senyawa Aktifnya. Disertasi. Program Pascasarjana Universitas Brawijaya Malang.

Robinson, T., 1995, Kandungan Organik Tumbuhan Tinggi, Edisi VI, Hal 191216, Diterjemahkan oleh Kosasih Padmawinata, ITB, Bandung.

Sanoesi, E. 2008. Penggunaan Ekstrak Daun Pepaya (Carica papaya Linn) terhadap Jumlah Sel Makrofag pada Ikan Mas (Cyprinus carpio L) yang Terinfeksi Bakteri Aeromonas hydrophila. Jurnal Penelitian Perikanan, Vol 11, No. 2, Desember 2008. 